medicine and biology.

Apart from ETH, Basle is the university that has profited the most from the Swiss chemical industry. The benefits are most visible at the Biozentrum, which was built with the help of a "catalytic unit" of SFr5 million according to Alfred Pletscher, who helped to create it.

There is continuing interaction in Basle in the form of industrial researchers who are also professors and of graduate students who do their thesis at a company. Basle Institute for Immunology members "do all the immunology teaching" in the natural sciences faculty at the University of Basle, says institute director Fritz Melchers. Sources on both sides say that the students are not "abused" by their advisers and that industry laboratories remain open to the university.

Jakob Nüesch. Ciba-Geigy's pharmaceutical research director, says that strong contacts between industry and academic institutions are "part of our tradition. New trends in industry must have their roots in university developments". Ciba-Geigy's pharmaceutical research department collaborates with eight groups in Basle as well as with researchers in Berne, Geneva, Zurich, Lausanne and with groups "from Texas to Canada", seeking "projects of mutual interest," says Nüesch. "We don't just place orders." About a third of the graduate students and postdocs at CibaGeigy return to work for the company.

When asked who gains more from the cooperation of industry with universities, the Biozentrum's Jeff Schatz calls it "a tie". Industry contributes to a "critical mass" of biomedical researchers and to the international atmosphere in Basle research, and industrial efficiency rubs off on university government. In turn, the three chemical giants have a steady supply of talent.

In other areas, university officials admit that the interaction between universities and Swiss industry could stand improvement. ETH, the University of Basle and others have established 'contact offices' which provide a list of past, current and future research projects and matches companies with research groups for collaboration.

Ralf Hütter, ETH vice-president for research, points to the need to improve contacts in electronics, for example. Some ETH institutes are at present supported with up to a quarter of their budget by industry, but others have no support at all.

Hütter would like to see a general industry support level of 15-20 per cent but no more. In the past, too much industry money has been put into short-term projects meant to yield quick solutions.

On the university side, Hütter says "we must educate people not to fear industry". He sees his task as "a challenge to establish a tradition in those fields where there was none before".

Engineering

\title{
Living in a material world
}

LAST year's merger of two electrical engineering giants into Asea Brown Boveri $(\mathrm{ABB})$ has breathed life into the Swiss half of the company. Although some rough spots lie ahead as 'restructuring' proceeds. Maurice Campagna, the new research director, foresees an improvement in ABB's interaction with Swiss universities, giving benefits on both sides.

The merger brought together Brown Boveri \& Cie, a Swiss machine and electrical systems company nearly a century old, and its Swedish rival ASEA. The resulting hybrid is one of the leading European providers of gas turbines and nuclear and conventional power plants as well as transportation and communication technology. Among other activities, it has helped to build a prototype underground train now being tested by the London 'tube'.

ABB is the self-proclaimed 'flagship' of the Swiss machine and metal industry, investing as much as SFr1,000 million a year in research and development. Companies producing machines, metals and electrical systems invest nearly half of the money put into research and development by Swiss industry each year (most of the rest comes from the chemical industry).

$\mathrm{ABB}$ research in Switzerland revolves around a centre in Dättwil, $30 \mathrm{~km}$ northwest of Zurich, which features research into environmental technologies, materials science, semiconductors and electronics. The location, says Campagna, makes it easy to attract foreign researchers - some 60 per cent of the scientific staff - who are then "willing to work harder" because of the close proximity of the Alps.

The 42-year-old Campagna, a Swiss national from the Italian-speaking canton of Ticino, joined ABB after a brief tenure as a professor of physics at ETH. Like so many ambitious Swiss, Campagna had left
Switzerland after his $\mathrm{PhD}$ for seasoning abroad. He returned in 1986 after five years at Bell Laboratories in the United States and nine years at the Jülich Nuclear Research Establishment in West Germany.

A key task for $\mathrm{ABB}$, he says, is to attract graduates away from high-glamour fields like biotechnology or pharmaceutical development by providing projects both "scientifically interesting and close to

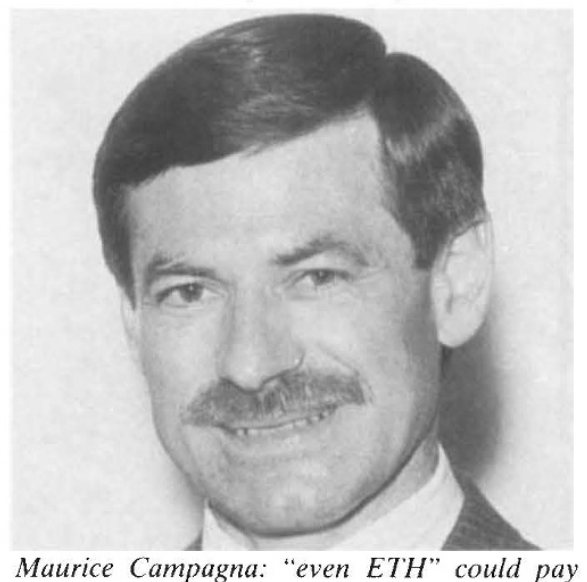
Maurice Campagna: "even ETH"
more attention to corporate needs.

the market". The growing share of ABB research into areas such as environmental engineering, in addition to the traditional areas such as gas turbines or power plant design, might provide the necessary pull.

At the same time, Campagna sees a need for researchers at the universities, even vaunted ETH, to pay more attention to corporate needs. Breakthroughs at ETH in semiconductor technology, for example, were not followed up (although the lack of a Swiss semiconductor industry also had something to do with this). For research in electrical engineering, Campagna says, ETH has been a "black hole."

S.D.

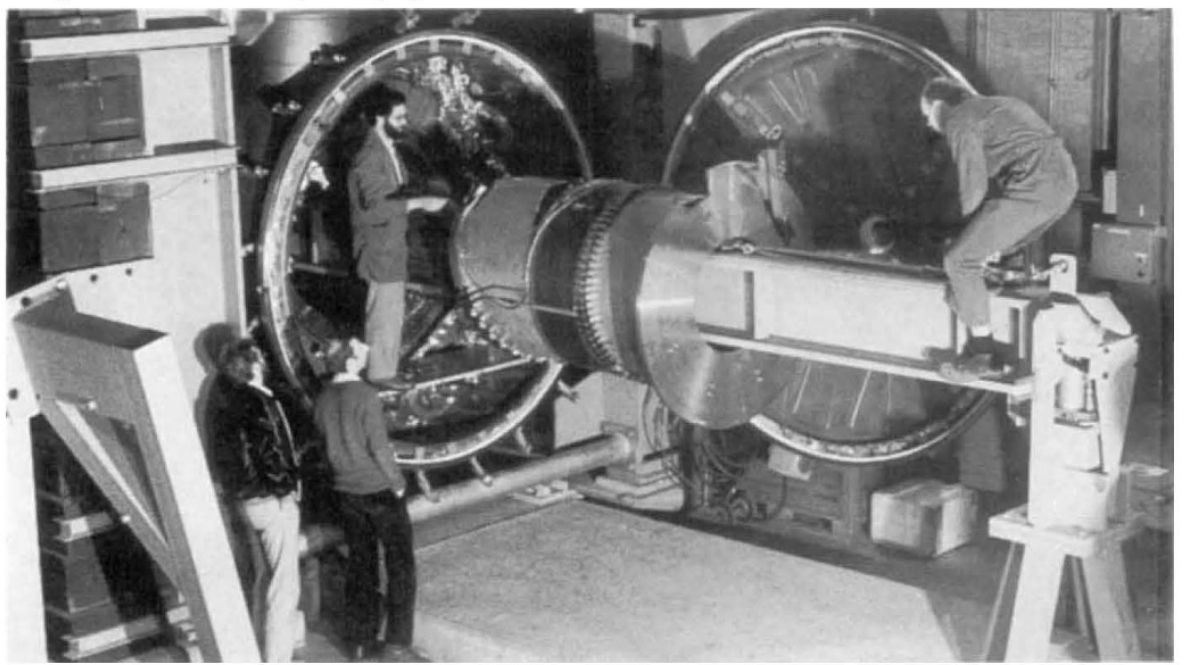

High-field test apparatus made by $A B B$ for the Swiss Paul Scherrer Institute for the testing of superconducting cables. 